\title{
Relationship of Front Line Employees' Emotional Intelligence to Co-Creation, Satisfaction, and Customer Loyalty in Banking Industry
}

\author{
Masoumeh Shoeib ${ }^{1}$, Shahram Salavati ${ }^{2}$
}

\begin{abstract}
This study evaluates the relationship between front line employees' emotional intelligence with cocreation and customer loyalty. The population under study consisted of expert and managerial level employees at the Pasargad Bank in Tehran; 323 subjects participated in the data gathering process and responded to the questionnaires of emotional intelligence, co-creation, loyalty, and customer satisfaction. Reliability and validity of the tools were assessed using Cronbach's alpha coefficient and confirmatory factor analysis. Pearson correlation coefficient, structural equation model, and Amos software were used to analyze the data. The results show that front line employees' emotional intelligence is associated with co-creation, loyalty, and customer satisfaction. In addition, the results confirm the relationship of co-creation and customer satisfaction to customer loyalty; it also suggests that emotional intelligence has an indirect positive and significant effect on customer loyalty through co-creation and customer satisfaction.
\end{abstract}

Keywords: Emotional intelligence, co-creation, customer satisfaction, customer loyalty.

\section{Introduction}

In the competitive market today, many organizations are losing their customers. But this loss of customers does not mean the need for customers to disappear, but they provide their need from another place. In addition, in today's competitive world, all commercial and service firms use every trick to achieve their goals to gain more market share. Meanwhile, obtaining customer satisfaction and loyalty, as well as providing specialized and desirable services to preserve them is regarded as a source of income that encourages them to refer back to the institution. In addition to repeatedly referring to his or her favorable organization for the purchase of products or the use of services, A loyal customer plays an important role in enhancing the profitability and improving the image of the organization in the minds of potential customers as a factor in promoting the organization's products and services, through recommendations and orders to relatives, friends or other people [9]. Researchers emphasize the positive relationship between customer loyalty and business performance [21]. Barroso Castro and Martín Armario [3] argue that loyal customers not only raise the value of business but also allow businesses to keep their costs low in comparison to attracting new customers. Harris and Goode [18] consider loyalty as a strong commitment to re-purchasing a product or service in the future, so that the same brand or product is purchased despite the potential impact of its competitors' marketing efforts. On this basis, it can be said that loyalty is a profound | 'Department of Business Administration, Tonekabon Branch,Islamic Azad University, Tonekabon, Iran. |2Assistant Professor, Department of Business Administration, Tonekabon Branch,Islamic Azad University, Tonekabon, Iran. Corresponding Author 
commitment to re-purchasing a superior product or service in the future, which means re-purchasing a brand, despite the environmental effects and the marketing actions of competitors to change behavior [20; 33]. Therefore identifying the factors affecting customer loyalty seems essential.

Several factors may contribute to overall customer loyalty. These factors may be factors related to the product and the manner in which it is provided or related to the customer. Meanwhile, the method of communicating sales staff or employees who are directly concerned with providing customer service or product can be an effective factor in promoting customer loyalty. Frontline employees' emotional intelligence effectively defines the quality of their behavior.

Customer-co-creation means that customers actively engage in some design, transformation, and experience-making practices [27]. In relationships and business networks, value co-creation for the customer can be examined from three perspectives: creating value for the customer, creating value for the supplier, and co-creation of value for the customer-supplier [34]. The customer's perspective refers to the way of superior value perceived by the seller's suggestion in comparison with the options available. The supplier's view considers customers' need as the key capital of the company and emphasizes the attraction and preservation of customers through customer capital management. Customer supplier perspective focuses on the co-creation of value through relationships, cooperation, alignment, and unity [34]. In the process of value co-creation, the company's resources are combined and new combinations of capabilities are developed; thus, they enable companies to achieve results that each of the sources alone could not produce such results. Recent research emphasizes the value of co-creation through the interaction between the buyer and the seller [8].

According to Porter's value chain (1985), in the process of value-co-creation, the customer is not outside the value creation process and is not considered as the inactive actor of the value-receiver, but the customer participates in value co- creation through interactions with partners and partners [26]. Researches have shown that value-cocreation has an impact on customer loyalty $[8 ; 22 ; 6 ; 13]$ because collaborative activities in the process of value-co-creation in the context of business services can greatly improve the perceived value of customers. One of the variables recently considered in the researches is the emotional intelligence of the staff $[15 ; 17]$. The term emotional intelligence comes from the belief that excitement is an important element of intelligence. Emotional intelligence is rooted in the concept of social intelligence, which was first identified by Thorndike (1920; 4). Social intelligence was later described by Gardner [11] as interpersonal and intrapersonal intelligences [2]. Emotional intelligence creates equilibrium between emotion and recognition that results in adaptive action [31]. The quadrilateral pattern of emotional intelligence shows that emotional intelligence is the result of interrelated abilities: 1) emotion perception in oneself and others; 2) using excitement to facilitate decision-making; 3) emotion comprehension; 4) control of selfexcitement and others' excitement. According to Bar On's combined pattern [16], emotional intelligence consists of emotional self-awareness and various characteristics and skills that can be deduced from effective application or regulation of emotions such as interpersonal relationships, problem solving, and stress tolerance. Emotional intelligence covers individual differences in personal emotional capabilities (stress 
control) and interpersonal emotional capabilities (stress perception) [30].

Studies about emotional intelligence show a significant relationship between employee's emotional intelligence and customer satisfaction and loyalty $[24 ; 10 ; 1 ; 25 ; 32 ; 19]$. In general, employees' emotional intelligence has a positive effect on co-creation and consequently on customer loyalty. Therefore, in order to increase the likelihood of such a positive partnership and the management of brand assets, companies need to develop strategies that increase and grow co-creation and, as a result, loyalty of customers. Despite the importance and attention to customer loyalty, few empirical studies have investigated the effect of employees' emotional intelligence and co-creation on customer loyalty within the framework of a causal model. In this regard, this research tries to uncover the amount of increase in the satisfaction and trust of customers who experience co-creation. In this manner, they can find the necessary amount for increasing emotional intelligence in order to create stronger connections with the company and become more loyal.

\section{Research Methodology}

The present study is an applied research based on its objectives. It can be considered as a descriptive-survey. The statistical population of the study includes expert and managerial level employees at the Pasargad Bank in Tehran. According to the obtained data, the total population includes 2484 people. The Cochran formula was used to determine the sample size. So, 333 employees from the category of experts and bankers in Pasargad Bank in Tehran were selected as subjects of the study. Simple random sampling method has been employed in order to get feedback from bank staffs. 350 questionnaires were distributed to ensure the return of the questionnaire. 338 questionnaires were returned, 15 questionnaires were excluded from the analysis because they were incompletely answered, and 323 questionnaires were analyzed. Different descriptive and inferential methods are used to analyze the data. For descriptive statistics, indicators such as percentage, mean, and standard deviation have been used while confirmatory factor analysis and structural equation modeling have been used for inferential methods. SPSS and AMOS softwares were used to analyze the data. In this research, alpha of over 0.7 is considered a suitable tool for reliability. Therefore, reliability measurement was performed using Cronbach's alpha and SPSS 21 software.

Table 1. Cronbach's alpha coefficients of research variables

\begin{tabular}{|l|c|}
\hline Variables & Cronbach's alpha \\
\hline Emotional Intelligence & 0.92 \\
\hline Customer satisfaction & 0.89 \\
\hline Value co-creation & 0.79 \\
\hline Costumer loyalty & 0.81 \\
\hline
\end{tabular}

\section{Research Findings}

\subsection{Confirmatory Factor Analysis of Data}

In order to enter the structural equations, the research tools must be verified for 
validating the construct. Confirmatory factor analysis has been used to verify each variable as well as each statement of the variables. In fact, confirmatory factor analysis is used to determine the fit of the measurement model. Confirmatory factor analysis is in fact a theory test model, in which the researcher begins his analysis with an assumed hypothesis. This model, which is based on a strong empirical and theoretical foundation, determines which variables are correlated with which factors and which factors are associated with which factors. It also provides the researcher with a reliable method for evaluating validity of constructs. In this way, he can test hypotheses about data factor structure that results from a predetermined model with a specific number and a combination of agents. By determining the fit of a predetermined factor model, confirmatory factor analysis tests optimal matching of observed and theoretical factor structures for the data set. After a brief explanation of fit indicators, this section analyzes confirmatory factor analysis related to each of the factors mentioned in the conceptual model.

\subsection{Confirmatory factor analysis of emotional intelligence}

As seen, the output of standardized coefficients of Amos for the emotional intelligence variable has been reported in Figure 1. All questions have factor loads higher than 0.3 and significant.

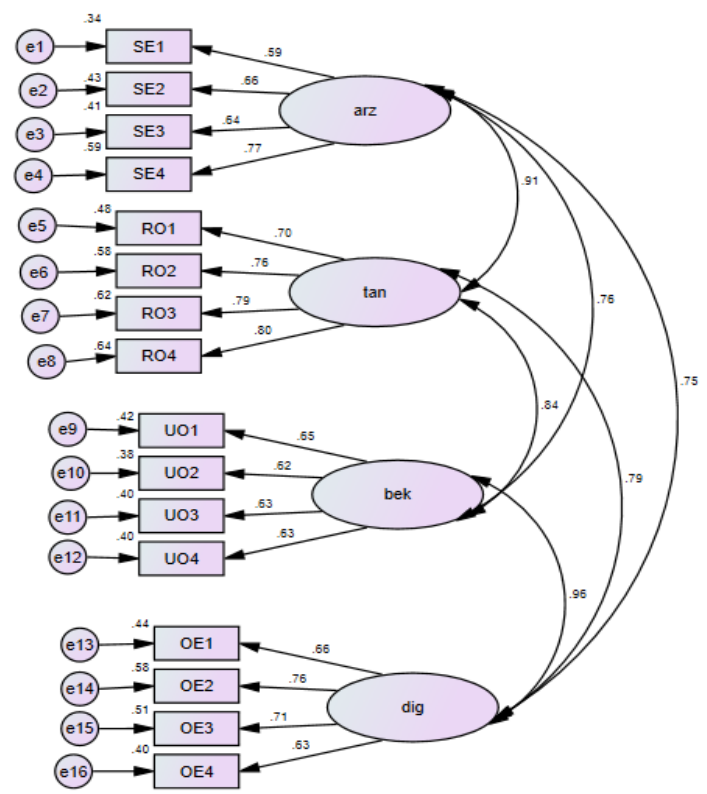

Figure 1. Amos output for emotional intelligence variable

According to Amos output, calculated $\mathrm{x}^{2} / \mathrm{df}$ value is 2.16 , the presence of $\mathrm{x}^{2} / \mathrm{df}$ smaller than 3 represents fitting of the model. Moreover, Root Mean Square Error of Approximation (RMSEA) should be less than 0.08, which is 0.06 in the proposed model. The GFI, AGFI, CFI, and NFI indices should also be more than 0.9, which are higher than the calculated model in the model under review. Therefore, the data of this research 
are fitted with the factor structure of this scale; this indicates the alignment of questions with the variable of emotional intelligence.

\subsection{Confirmatory factor analysis of value co-creation}

As seen, the output of standardized coefficients of Amos for the value cocreation variable has been reported in Figure 2. All questions have factor loads higher than 0.3 and significant.

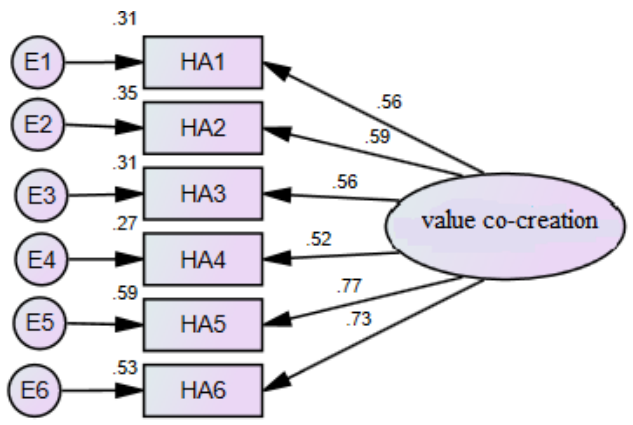

Figure 2. Amos output for value co-creation variable

According to Amos output, calculated $\mathrm{x}^{2} / \mathrm{df}$ value is 2.19 , the presence of $\mathrm{x}^{2} / \mathrm{df}$ smaller than 3 represents fitting of the model. Moreover, Root Mean Square Error of Approximation (RMSEA) should be less than 0.08, which is 0.061 in the proposed model. The GFI, AGFI, CFI, and NFI indices should also be more than 0.9, which are higher than the calculated model in the model under review. Therefore, the data of this research are fitted with the factor structure of this scale; this indicates the alignment of questions with the variable of value co-creation.

\subsection{Confirmatory factor analysis of customer satisfaction}

As seen, the output of standardized coefficients of Amos for the customer satisfaction variable has been reported in Figure 3. All questions have factor loads higher than 0.3 and significant.

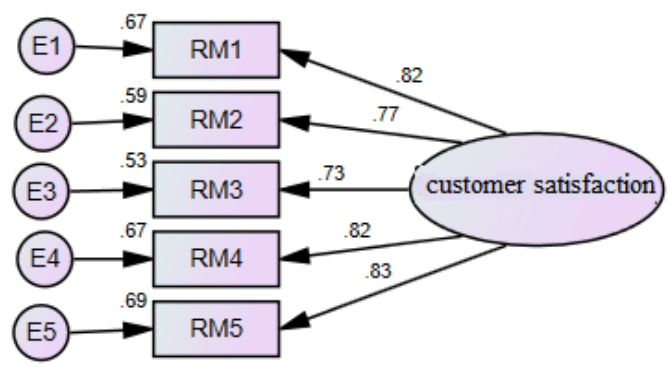

Figure 3. Amos output for customer satisfaction variable

According to Amos output, calculated $\mathrm{x}^{2} / \mathrm{df}$ value is 2.04 , the presence of $\mathrm{x}^{2} / \mathrm{df}$ smaller than 3 represents fitting of the model. Moreover, Root Mean Square Error of 
Approximation (RMSEA) should be less than 0.08, which is 0.057 in the proposed model. The GFI, AGFI, CFI, and NFI indices should also be more than 0.9 , which are higher than the calculated model in the model under review. Therefore, the data of this research are fitted with the factor structure of this scale; this indicates the alignment of questions with the variable of customer satisfaction.

\subsection{Confirmatory factor analysis of customer loyalty}

As seen, the output of standardized coefficients of Amos for the customer loyalty variable has been reported in Figure 4. All questions have factor loads higher than 0.3 and significant.

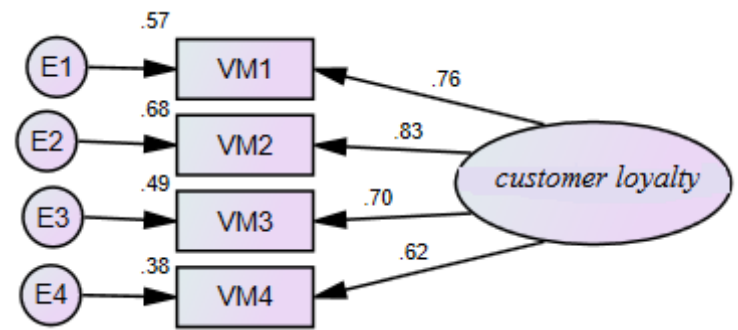

Figure 4. Amos output for customer loyalty variable

According to Amos output, calculated $\mathrm{x}^{2} / \mathrm{df}$ value is 1.43 , the presence of $\mathrm{x}^{2} / \mathrm{df}$ smaller than 3 represents fitting of the model. Moreover, Root Mean Square Error of Approximation (RMSEA) should be less than 0.08, which is 0.036 in the proposed model. The GFI, AGFI, CFI, and NFI indices should also be more than 0.9, which are higher than the calculated model in the model under review. Therefore, the data of this research are fitted with the factor structure of this scale; this indicates the alignment of questions with the variable of customer loyalty.

\subsection{Descriptive indexes of research variables}

Table 1 represents indicators of descriptive statistics for the sample including mean and standard deviation for the variables studied in this research.

Table 2. Descriptive indexes of research variables

\begin{tabular}{|l|l|l|}
\hline Variables & Mean & Standard deviation \\
\hline Emotional intelligence & 3.16 & 0.73 \\
\hline Customer satisfaction & 2.96 & 0.97 \\
\hline Value co-creation & 2.82 & 0.78 \\
\hline Costumer loyalty & 2.99 & 0.90 \\
\hline
\end{tabular}

\subsection{Data Normality Test}

Kolmogorov-Smirnov test has been used to ensure the normality of the data collected by statistical distributions. This test aims to uncover whether the distribution of variables is normal or not.

Null hypothesis and alternative hypothesis to test data normality are as following: H0: Data are distributed normally. 
H1: Data are not distributed normally.

Given that parametric methods are used in societies with normal functions and nonparametric methods are used in non-normalized societies, normal or abnormal distribution of research data should be examined at first. Kolmogorov-Smirnov (KS) test is employed in this regard. If the research data is normal, Pearson correlation coefficient will be used and otherwise the Spearman correlation coefficient, which is a nonparametric method, will be used to test the research hypotheses.

Table 3. Kolmogorov Smirnov test to examine research variables normality

\begin{tabular}{|l|c|c|}
\hline Variables & $\mathbf{Z}$ & Significance level \\
\hline Emotional intelligence & 0.750 & 0.627 \\
\hline Customer satisfaction & 1.19 & 0.116 \\
\hline Value co-creation & 1.123 & 0.085 \\
\hline Costumer loyalty & 1.03 & 0.234 \\
\hline
\end{tabular}

According to Table 2, Kolmogorov-Smirnov test shows that significance level for all variables is not significant. Hence, null hypothesis (data normality) is confirmed and alternative hypothesis (data abnormality) is rejected. Therefore, Pearson correlation coefficient test and structural equation modeling are used to examine the research hypotheses.

\subsection{Research Variables Correlation}

After determining the validity of measurement tools, identifying the relationship between variables is the next step is to enter the discussion of structural equations., Pearson correlation coefficient has been used to determine the relationship between the present variables in the model. The results of the correlation coefficient between the variables of research are included in Table 3. The findings show that the correlation coefficient of emotional intelligence is positive and significant at 0.01 level with customer satisfaction $(r=0.59)$, value co-creation $(r=0.55)$ and customer loyalty $(r=0.56)$. The correlation coefficient of customer satisfaction is positive and significant at 0.01 level with value co-creation $(\mathrm{r}=0.52)$ and customer loyalty $(\mathrm{r}=0.58)$. The correlation coefficient of co-creation and customer loyalty $(\mathrm{r}=0.58)$ is positive and significant at 0.01 level.

Table 4. Correlation matrix of research constructs

\begin{tabular}{|l|c|c|c|c|}
\hline Variables & $\begin{array}{c}\text { Emotional } \\
\text { intelligence }\end{array}$ & $\begin{array}{c}\text { Customer } \\
\text { satisfaction }\end{array}$ & $\begin{array}{c}\text { Value co- } \\
\text { creation }\end{array}$ & $\begin{array}{c}\text { Costumer } \\
\text { loyalty }\end{array}$ \\
\hline Emotional intelligence & 1 & & & \\
\hline Customer satisfaction & $0.59^{* *}$ & 1 & & \\
\hline Value co-creation & $0.55^{* *}$ & $0.52^{* *}$ & 1 & \\
\hline Costumer loyalty & $0.56^{* *}$ & $0.61^{* *}$ & $0.58^{* *}$ & 1 \\
\hline
\end{tabular}

Figure 5 represents tested model for research hypotheses along with standardized values on each of the paths. The findings show that the effect of emotional intelligence on the customer satisfaction, value co-creation, and customer loyalty is positive and significant. 
The effect of value co-creation and customer satisfaction on customer loyalty is positive and significant.

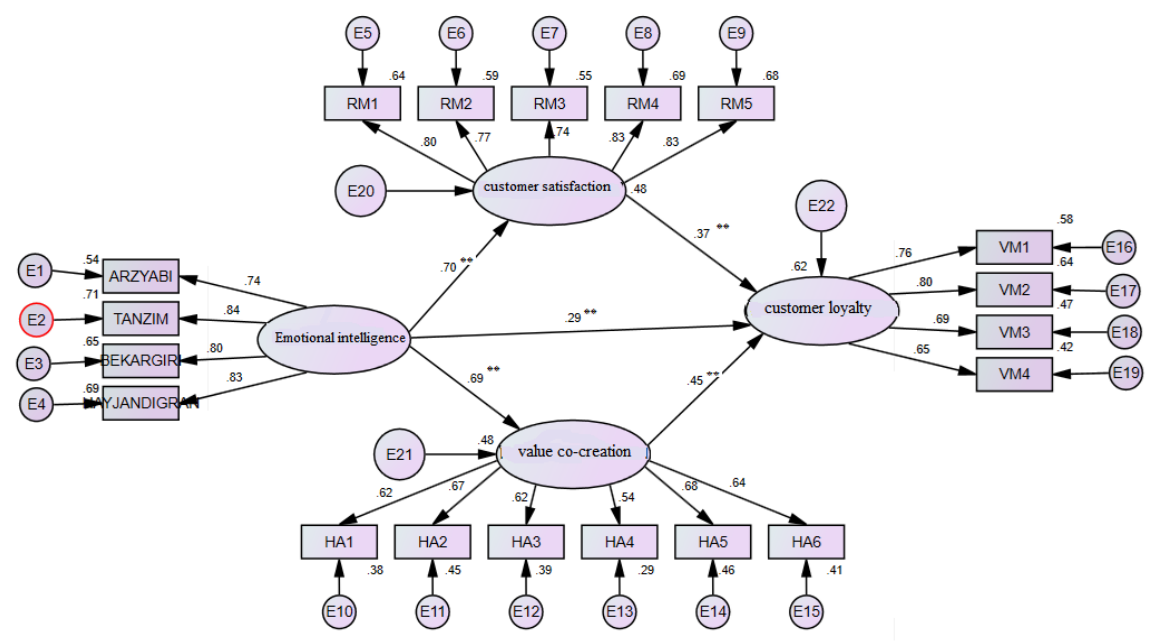

Figure 5. Research-tested model

Table 4 displays direct and indirect effects as well as variance explained of the research variables.

Table 5. The results of the tested model

\begin{tabular}{|c|c|c|c|}
\hline Paths & Direct effect & $\begin{array}{c}\text { Indirect } \\
\text { effect }\end{array}$ & $\begin{array}{c}\text { Variance } \\
\text { explained }\end{array}$ \\
\hline \multicolumn{3}{|l|}{ On customer loyalty from: } & \multirow{4}{*}{$62 \%$} \\
\hline Customer satisfaction & $0.37 * *(4.923)$ & - & \\
\hline Value co-creation & $0.45^{* *}(5.077)$ & - & \\
\hline Emotional intelligence & $0.29 * *(3.426)$ & $0.57(8.982)$ & \\
\hline \multicolumn{3}{|l|}{ On customer satisfaction from: } & \multirow{2}{*}{$48 \%$} \\
\hline Emotional intelligence & $0.70 * *(11.252)$ & - & \\
\hline \multicolumn{3}{|l|}{ On value co-creation from: } & \multirow{2}{*}{$48 \%$} \\
\hline Emotional intelligence & $0.69 * *(9.199)$ & - & \\
\hline $\begin{array}{l}\text { Mediating role of customer satisfaction in } \\
\text { relationship between employees' emotional } \\
\text { intelligence and customer loyalty: }\end{array}$ & \multicolumn{3}{|c|}{$0.26^{* *}(4.510)$} \\
\hline $\begin{array}{l}\text { Mediating role of value co-creation in } \\
\text { relationship between employees' emotional } \\
\text { intelligence and customer loyalty: }\end{array}$ & \multicolumn{3}{|c|}{$0.31 * *(4.519)$} \\
\hline
\end{tabular}

${ }^{*} \mathrm{p}<0.05 ;{ }^{* *} \mathrm{p}<0.01$

The results of Table (8) show that the effect of emotional intelligence on the customer satisfaction, value co-creation, and customer loyalty is positive and significant. The effect of value co-creation and customer satisfaction on customer loyalty is positive and significant. The mediating role of customer satisfaction in the relationship between 
employees' emotional intelligence and customer loyalty is positive and significant. The mediating role of value co-creation in the relationship between employees' emotional intelligence and customer loyalty is positive and significant. As shown in Table 8, 62\% of customer loyalty variance, $48 \%$ of customer satisfaction variance, and $48 \%$ of variance of value co-creation are explained by the variables in the present research model. The fitting indices obtained for the tested model indicate that the RMSEA index has an acceptable level of 0.054 in the estimated model. Moreover, other fitness indexes such as CFI, GFI, NFI, and AGFI are respectively 0.98, 0.93, 0.95, and 0.91; thus, they are acceptable. These goodness of fit features show that the data from this research is fit with the constructs of the model. Table 5 reports results of testing research hypotheses.

Table 6. Results of testing research hypotheses

\begin{tabular}{|l|l|}
\hline Hypothesis & \multicolumn{1}{|c|}{$\begin{array}{c}\text { Test } \\
\text { result }\end{array}$} \\
\hline $\begin{array}{l}\text { Frontline employees' emotional intelligence is associated with the co-creation of } \\
\text { the customer. }\end{array}$ & Confirmed \\
\hline Frontline employees' emotional intelligence is related to customer loyalty. & Confirmed \\
\hline Frontline employees' emotional intelligence is related to customer satisfaction. & Confirmed \\
\hline Co-creation is related to customer loyalty. & Confirmed \\
\hline Satisfaction is related to customer loyalty. & Confirmed \\
\hline $\begin{array}{l}\text { Co-creation of the customer is mediator in the relationship between the front line } \\
\text { employees' emotional intelligence and customer loyalty. }\end{array}$ & Confirmed \\
\hline $\begin{array}{l}\text { Customer satisfaction is mediator in the relationship between the front line } \\
\text { employees' emotional intelligence and customer loyalty. }\end{array}$ & Confirmed \\
\hline
\end{tabular}

\section{Conclusion}

First hypothesis: Frontline employees' emotional intelligence is associated with the co-creation of the customer.

The results showed that frontline employees' emotional intelligence is related to the customer's co-creation. So frontline employees' emotional intelligence leads to increase in customer co-creation. This finding suggests that emotional intelligence of employees makes the customers participate in the development of the new product of the bank actively, share long-term plans of their products with customers, customers and banks participate in solving problems in the process of communication with each other, responsibility for doing things and work is divided in many aspects of relationships with buyers, bank is responding to changes that are made in relation to customers, and customers and the bank work together to solve unexpected events.

\section{Second hypothesis: Frontline employees' emotional intelligence is related to customer loyalty.}

The results show that front line employees' emotional intelligence is related to customer loyalty. So frontline employees' emotional intelligence leads to increase in customer loyalty. This finding is consistent with the findings of Mufidi and Moalemi Bahmani [24], A'lam [1] and Nasiri Asl [25]. Emotional intelligence is one of the components that can greatly play a role in other people's relationships. According to Goleman [14], it is a definite and inevitable condition in the organization. Employees that have emotional 
intelligence are effective employees who achieve goals with maximum productivity, satisfaction and commitment [32]. Today, many organizations are undergoing change, and any change requires employees and managers who are adaptable and compatible to change.

\section{Third hypothesis: Frontline employees' emotional intelligence is related to} customer satisfaction.

The results show that front line employees' emotional intelligence is related to customer satisfaction. So frontline employees' emotional intelligence leads to increase in customer satisfaction. This finding is consistent with the findings of Mufidi and Moalemi Bahmani [24], A'lam [1], and Nasiri Asl [25]. In explaining this finding, one can say that employees with high emotional intelligence, with an emphasis on recognizing the emotions and emotions of others ideally, fulfill the expectations of customers to the extent that they can. In addition, employees with high emotional intelligence emphasize empathy and the good ability to manage relationships as well as individual considerations [19]. As a result, they increase customer satisfaction and make customers happy with their decision to use bank services, have many positive experiences with using bank services, feel comfortable in using bank services, and believe that their choice to use bank services is a wise choice.

\section{Fourth hypothesis: Co-creation is related to customer loyalty.}

The results showed that value co-creation is related to customer loyalty. So frontline employees' value co-creation leads to increase in customer loyalty. This finding is consistent with the findings of Giner and Rillo [13], Cossio-Silva et al. [8], Chen et al [6], Wang et al. [32], and Ranjan et al. [28]. In explaining this finding, it can be said that customer loyalty will increase if customers participate in the development of the new product of the bank actively, share long-term plans of their products with customers, customers and banks participate in solving problems in the process of communication with each other, responsibility for doing things and work is divided in many aspects of relationships with buyers, bank is responding to changes that are made in relation to customers, and customers and the bank work together to solve unexpected events.

\section{Fifth hypothesis: Satisfaction is related to customer loyalty.}

The results showed that satisfaction is related to customer loyalty. So frontline employees' satisfaction leads to increase in customer loyalty. This finding is in line with the findings by Motaharinejad et al [23], Ghorbani et al [12], Choi and Kim [7], Chen and Lee [5], and Michel-Romero et al [29]. This finding indicates that customer loyalty to the company will be higher when customers are satisfied with the company's services, their expectations are satisfied, they have experience of the satisfaction of the company's services, the atmosphere of dealing with customers is friendly, company's employees provide accurate information on the way to provide services to customers, respond to customer requests, respond to customers with issues and problems, and they provide high quality services.

Sixth hypothesis: Co-creation of the customer is mediator in the relationship between the front line employees' emotional intelligence and customer loyalty.

The results showed that emotional intelligence has a positive and significant indirect effect on customer loyalty. Therefore, customer co-creation is the mediator of relationship between front line employees' emotional intelligence and customer loyalty. As a result, emotional intelligence can increase customer loyalty by influencing customer 
co-creation.

\section{Seventh hypothesis: Customer satisfaction is mediator in the relationship between the front line employees' emotional intelligence and customer loyalty.}

The results showed that emotional intelligence has a positive and significant indirect effect on customer loyalty. Therefore, customer satisfaction is the mediator of relationship between front line employees' emotional intelligence and customer loyalty. As a result, emotional intelligence can increase customer loyalty by influencing customer satisfaction.

In general, the results showed that frontline employees' emotional intelligence is related to the customer's co-creation. Frontline employees' emotional intelligence leads to increase in customer co-creation. Frontline employees' emotional intelligence is related to customer loyalty. Thus, frontline employees' emotional intelligence leads to increase in customer loyalty. Frontline employees' emotional intelligence is related to customer satisfaction. Thus, frontline employees' emotional intelligence leads to increase in customer satisfaction. Value co-creation is related to customer loyalty. Therefore, frontline employees' emotional intelligence leads to increase in customer loyalty. Customer satisfaction is related to customer loyalty. Therefore, frontline employees' emotional intelligence leads to increase in customer loyalty. Emotional intelligence has a positive and significant indirect effect on customer loyalty. Therefore, customer cocreation is mediator of the relationship between front line employees' emotional intelligence and customer loyalty. Emotional intelligence has a positive and significant indirect effect on customer loyalty. Therefore, customer satisfaction is mediator of the relationship between front line employees' emotional intelligence and customer loyalty. The results show that front line employees' emotional intelligence is related to customer co-creation, customer satisfaction, and customer loyalty. Accordingly, it is suggested for managers and authorities at Pasargad Bank in Tehran to hold workshops on "promoting emotional intelligence of employees and managers" in order to increase the emotional intelligence of employees and managers. By increasing emotional intelligence, employees' ability to recognize, access, and create emotions to help thinking, understanding emotions as well as emotional awareness, and moderating the thoughtful excitement will be enhanced in order to promote the emotional and rational growth of the employees.

\section{References}

A'lam, A. (2013). Investigating the Effect of Employees Emotional Intelligence on Satisfaction of the Customers of the Refah Bank of Tehran. Master's Thesis, Islamic Azad University, Tehran Central Branch.

Bar-On, R., Brown, J. M., Kirkcaldy, B. D., \& Thome, E. P. (2000). Emotional expression and implications for occupational stress; an application of the Emotional Quotient Inventory (EQ-i). Personality and individual differences, 28(6), 1107-1118.

Castro, C. B., \& Armario, E. M. (1999). Marketing relacional. ESIC Editorial.

Chen, Z., Lam, W., \& Zhong, J. A. (2010). Effects of perceptions on LMX and work performance: Effects of supervisors' perception of subordinates' emotional intelligence and subordinates' perception of trust in the supervisor on LMX and, consequently, performance. Asia Pacific journal of management, 29(3), 597-616. 
Chen, C. M., Chen, S. H., \& Lee, H. T. (2013). Interrelationships between physical environment quality, personal interaction quality, satisfaction and behavioural intentions in relation to customer loyalty: The case of Kinmen's bed and breakfast industry. Asia Pacific Journal of Tourism Research, 18(3), 262287.

Chen, C. F., \& Wang, J. P. (2016). Customer participation, value co-creation and customer loyalty-A case of airline online check-in system. Computers in Human Behavior, 62, 346-352.

Choi, D., \& Kim, J. (2004). Why people continue to play online games: In search of critical design factors to increase customer loyalty to online contents. CyberPsychology \& behavior, 7(1), 11-24.

Cossío-Silva, F. J., Revilla-Camacho, M. Á., Vega-Vázquez, M., \& Palacios-Florencio, B. (2016). Value cocreation and customer loyalty. Journal of Business Research, 69(5), 1621-1625.

Dadkhah, M. (2009). Customer Orientation. Shahr Ashob Publication, Sixth Edition, Tehran, Center for Applied Science and Culture and Art, Unit 38, Tehran.

Fayaz Safuri, M., \& Mehrani, H. (2013). The Relationship between Emotional Intelligence of Employees with Customer Loyalty in National Bank Branches of Gorgan, Gonbad, and Ali Abad. Second National Conference on Accounting, Financial Management, and Investment.

Gardner, H. (1983). Frames of Mind. New York: Basic Book.

Ghorbani, H., \& Mousavi, S. M. (2014). The study impact of consumer personality traits on brand personality and brand loyalty (Case Study: product group of Isfahan Iran Khodro). International Journal of Academic Research in Business and Social Sciences, 4(1), 371.

Giner, G. R., \& Rillo, A. P. (2016). Structural equation modeling of co-creation and its influence on the student's satisfaction and loyalty towards university. Journal of Computational and Applied Mathematics, 291, 257-263.

Goleman, D. (1998). Working with emotional intelligence. Bantam.

Gooty, J., Connelly, S., Griffith, J., \& Gupta, A. (2010). Leadership, affect and emotions: A state of the science review. The Leadership Quarterly, 21(6), 979-1004.

Greven, C., Chamorro-Premuzic, T., Arteche, A., \& Furnham, A. (2008). A hierarchical integration of dispositional determinants of general health in students: The Big Five, trait emotional intelligence and humour styles. Personality and Individual differences, 44(7), 1562-1573.

Harms, P. D., \& Credé, M. (2010). Emotional intelligence and transformational and transactional leadership: A meta-analysis. Journal of Leadership \& Organizational Studies, 17(1), 5-17.

Harris, L. C., \& Goode, M. M. (2004). The four levels of loyalty and the pivotal role of trust: a study of online service dynamics. Journal of retailing, 80(2), 139-158.

Hur, W. M., Moon, T. W., \& Jung, Y. S. (2015). Customer response to employee emotional labor: the structural relationship between emotional labor, job satisfaction, and customer satisfaction. Journal of Services Marketing, 29(1), 71-80.

James E. Bartlett, 11 , Joe W.Kortrlik, Chdwick C. Higgins(2001) Organizational Research : Determining Appropriate Sample Size in Survey. Research Information Technology, and Performance Journal, 19(1): 4446.

Kandampully, J., Zhang, T., \& Bilgihan, A. (2015). Customer loyalty: a review and future directions with a special focus on the hospitality industry. International Journal of Contemporary Hospitality Management, 27(3), 379-414.

Mathis, E. F., Kim, H. L., Uysal, M., Sirgy, J. M., \& Prebensen, N. K. (2016). The effect of co-creation experience on outcome variable. Annals of tourism research, 57, 62-75.

Motahhari Nejad, F, Samadi, S, Toulabi, Z. and Pour AshrafY. (2014). "investigation of relationship between brand and consumer", journal of marketing management, number 23, pp: 127-147.

Mufidi, F., \& Moalemi Bahmani, M. (2015). The Relationship between Emotional Intelligence of Employees of Hormozgan Water and Wastewater Company with Satisfaction of Clients. International Conference on New Findings in Research on Psychology and Educational Sciences.

Nasiri Asl, A. (2011). The Relationship between Employees Emotional Intelligence and Customer Loyalty (Case Study: Iran Insurance Branches in Fasa). Master's thesis, Sistan and Baluchestan University.

Normann, R., \& Ramirez, R. (1993). From value chain to value constellation: Designing interactive strategy. Harvard business review, 71(4), 65-77.

Rajah, E., Marshall, R., \& Nam, I. (2008). Relationship glue: customers and marketers co-creating a purchase experience. NA-Advances in Consumer Research Volume 35. 
Ranjan, K. R., \& Read, S. (2016). Value co-creation: concept and measurement. Journal of the Academy of Marketing Science, 44(3), 290-315.

Romero Esquijarosa, M. (2014). Sistema de Información para el control del trabajo operativo en Tropas Guardafronteras de Cienfuegos (Doctoral dissertation, Universidad Central "Marta Abreu" de Las Villas).

Saklofske, D. H., Austin, E. J., Galloway, J., \& Davidson, K. (2007). Individual difference correlates of health-related behaviours: Preliminary evidence for links between emotional intelligence and coping. Personality and individual differences, 42(3), 491-502.

Schutte, N. S., Malouff, J. M., Thorsteinsson, E. B., Bhullar, N., \& Rooke, S. E. (2007). A meta-analytic investigation of the relationship between emotional intelligence and health. Personality and individual differences, 42(6), 921-933.

Wang, Z., Singh, S., Li, Y., Mishra, S., Ambrose, M., \& Biernat, M. (2015). Effects of Employees' Positive Affective Displays on Customer Loyalty Intentions: An Emotions-As-Social-Information Perspective. Academy of Management Journal, amj-2014.

Watson IV, G. F., Beck, J. T., Henderson, C. M., \& Palmatier, R. W. (2015). Building, measuring, and profiting from customer loyalty. Journal of the Academy of Marketing Science, 43(6), 790-825.

Zhang, J., Jiang, Y., Shabbir, R., \& Du, M. (2015). Building industrial brand equity by leveraging firm capabilities and co-creating value with customers. Industrial Marketing Management, 51, 47-58. 